\title{
University's Press Management to Increase the Quality of Education in University
}

\author{
Kundharu Saddhono, Budhi Setiawan \\ Universitas Sebelas Maret \\ Surakarta, Indonesia \\ kundharu.uns@gmail.com
}

\begin{abstract}
The purpose of the research to describe that publisher of university was since early with spirit and intention to encourage and support the implementation of "university tri dharma" especially in the field of publication. The approach used in the research is qualitative descriptive. Qualitative research is done to describe the model of university press development in any universities which are located in Central Java and DIY. Book publication can accelerate the implementation of "university tri dharma", the first is, education and teaching. The lecturers are expected to actively send the script of book to university press in the concerned university. Second, the result of research done by both lecturers and student in expected that the publication of research result can spread to the society. The publication also encourage the success of second dharma implementation, that is, research. Third, the famous knowledge on practical skill. The utility of the publication is in line with third dharma. University press as a supporter of tri dharma implementation has to have responsibility to publish asset of intellectual university to the society. The published book is expected to be able to give scientific contribution in the international world. Therefore, it must have management of professional publication.
\end{abstract}

Keywords-university's press, tri dharma, publication, education, quality, and books

\section{INTRODUCTION}

The world of publication is one important area that academicians need to take care of. They are supposed to participate in such area in the forms of scientific books, handbooks, textbooks, monographs, journals, and so on. This activity that academicians might widespread their thoughts to people within or outside the campus as their sources of knowledge. The university has a key role to offer and encourage its faculties to publish their scientific works. The university, through its body of publication (the press), serves as the gatekeepers of ideas [1] which is not merely responsible to participate in the books business but also to create scientific society [2]. The point is that books are important mean to increase one's inelegancy and this will also work when books are placed in a general situation that I contribute to the development of the inelegancy. Thus books are input as well as output of collective inelegancy, and it is the responsibility of the university's press to produce qualified and useful books [3] [4]
Tri Dharma in Indonesia are the three basic pillars of mindset and become an obligation for higher education as intellectuals in this country. The main task of a lecture is Tri Dharma of higher education that Tri dharma is taken from the Sanskrit word is "Tri" meaning three, and "Dharma" which means the obligation. Tri dharma of higher education is one of the basic responsibilities of the campus community to be developed simultaneously and together. The contents of Tri Dharma; The first is education and teaching. While studying in higher education, faculty teases various knowledge. Knowledge gained comes from different sources, but in social life should be no such thing as the process of give and take. The second is research and development. An article is not going to be the article if we just make that up and do not write in sentences. So also with the knowledge that science will not be used if it is not applied in real form. Lecturers who have done the research required to develop and implement it with the hopes of benefiting the community at a later date. The third is community service. Community service activities are carried out to the community and the benefits can be felt. From here the community is expected to be rewarded at the higher education who can assist universities in developing education and technology [5]

\section{LITERATURE REVIEW}

University press has an organizational structure that is different and very varied. In general, university press called the Institute for Publishing University or Technical Implementation Unit. This is based on observations and surveys that have been done over the last five years [6]. The role of publishers in each university depending on what is desired by the leadership of the university. In general vision, mission, purpose, and function of university press adapted to the vision, mission, goals, and functions of the college. The organizational structure of university press should clear its presence within the university organization. At the university press in Indonesia there are some sorts of organizations. There is a form of technical implementation unit, there is a form $\mathrm{CV}$, there is a foundation, and there is also a form of business [7] Various forms of existing organizations each have advantages and disadvantages. However, to note is the publishing business success depends on three things: (1) where the issuer is located, (2) the leadership of the university, and (3) the leadership of the manager of the issuer itself [8]. In the exposure of experience to manage the university press to set at least to 
consider four main aspects of the organization of the university book publishing, namely human resources, funding and costs, facilities and infrastructure, marketing and production [9]. The organization's management should use a publishing business functions within the management theory of evolution known as management by function. Management focuses on individual operational functions, for example, from the input to the output, each running its functions in accordance with the achievement of quality targets. The concept of total quality management (TQM) introduced by Heizer \& Render as Kyzen concept can also be applied in the publishing world, as the publisher of college [10]. Operational management of university press consists of (1) Management of Editorial Affairs; In the editorial midwife management, the thing to note is related to the script, the script requirements, source texts, manuscripts considerations, administrative texts, copyright and publishing agreement, and the ISBN / ISSN; 2 Management of Production; Management areas of production include production work stages manuscripts (preprints, printing processes, and post print) and price or cost of production; Management Marketing and Distribution; Management areas of marketing and distribution covers the scope of the market and marketing, warehousing, network marketing, and distribution; and (4) Management fields of administration and finance include the role of the administration, operating costs and profit and loss statements, publications and documentation [11]

\section{MATERIALS AND METHODS}

The approach used in this research is descriptive qualitative. Qualitative research conducted to describe the development of a model college university press in Central Java and Yogyakarta. It also conducted Focus Group Discussion (FGD), seminars, workshops, and training. Subjects of this study include: (1) institutions associated with the university press is Pusgrafin as Trustees of the University of press in Indonesia and the association of university press in Indonesia, Indonesian Association of University Press (AUPI) and Indonesian Universities Publishers Association (APPTI), (2) university press in college Central Java and Yogyakarta found in Graphic and Media Directory 2007-2008 [3], the UNS Press (Surakarta), UNNES Press (Semarang), UMS Press (Surakarta), ISI Press (Solo), UNDIP Press (Semarang), Unsoed Press (Purwokerto), and Gama Press (Yogyakarta), and UNY Press (Yogyakarta), and (3) personally involved in the university press as university leaders, faculty, management and staff of the university press, as well as students.

The data source of this research include: (1) Informant: institutional leader's builder university press, university leaders, professors, leaders and staff university press, as well as students. (2) Events, the events of the ongoing management of university press in Central Java, both in the preparatory process of publishing, preprints, printing process, and the process print post. (3) The document, which is a type of written information, which includes: (a) the results of university press publications, (b) the management activity and mechanism of action of university press, and (c) the transcript of the interview with the informant.

As the above data sources, data collection techniques used in this study include: (1) Questionnaire; The questionnaire used to gather data about perceptions builder university press, university leaders, professors, leaders and staff university press, and students. (2) Interview; In-depth interviews (depth interviewing) made to the builder university press, university leaders, faculty, management and staff of the university press, and students. (3) Observation; of observation was conducted to collect data related to the activities and management of university press in Central Java and we jump to the object of research. (4) Document analysis; Document analysis conducted on all written information, either express or implied. The documents were analyzed as has been stated in the source data.

\section{RESULT AND DISCUSSION}

The establishment of university's press is grounded in the spirit of encouraging the implementation of tri dharma perguruan tinggi (the three basic pillars of higher education) [12]. In line with spirit, university's press publishes, at the first place, textbooks. The publications of such books is expected to foster the implementation of first dharma, namely teaching and learning. Lectures of university are encouraged to send down their manuscript to be published into this kind of books. Secondly, the result of research carried out by lecturers and students can also support the implementation of the second dharma, namely, researching. Thirdly, this activity can support the production of scientific books for practical skills. While the first and second types of books are mostly for the society inside and outside of the campus, the third kind of books has much more functions, such as being used by student who are having their community service (called KKN) in certain villages where they have to help the people there with their applied knowledge, in line with third dharma.

With regard to the paradigm of university's press management which acts as a learning organization a works in a holistic a systemic manner, Ana Nadhya Abrar offers three important frame works that can be a guidance in the development of the press; the three frameworks are (1) press as an attempt to build science-based society, (2) press as an anticipation to knowledge bang, and (3) press as establisher of the university [13].

Globalization has brought several new customs for the people to access knowledge. With the advancement of technology, people have a wider access to knowledge from variety of disciplines. For instance, with the existence of email, nowadays people may download books containing knowledge. This can more or less reduce the people's dependency on conventional books. Nevertheless, the less dependence behavior on books would be no big deal for the press as long as the science-based society could be established with entails the following characteristics: (1) critical, meaning that people able to distinguish good things (to be used) from the bad ones (to be abandoned); (2) skeptical, meaning that people do not just believe on information served to them; (3) open-minded, meaning that people welcome values that may be different from theirs; and (4) universal, meaning that people use 
universal standards all the time in accomplishing their work [14].

University's press must take a part in building sciencebased society. It is their job to publish textbooks, readers, reference books, and reports of research. Through this book people can learn something. Furthermore, this book may also encourage people to adapt with reality that surround them with regard to advancement of technology. Unfortunately, the number of books that has been published is not enough. Uninteresting appearance of the books and lack of networks, book published by university's press mostly fail to compete with other books published by another publisher. To deal with it, university's press need to apply the direct-selling strategy to market this books. Another way is to cooperate with mass media to promote the books. Information served by mass media is able to create curiously among people, thus hoped to encourage them to find the book.

Leaving behind the $20^{\text {th }}$ century, the $21^{\text {st }}$ century is marked with huge social transformation. As a consequence, the role of university moves to knowledge server in which it has to provide knowledge within the interest of the society. The society itself has now regarded university as a good provider of knowledge and better life. It is not surprising, the 21 st century is considered as the age of knowledge. Those who are lack of knowledge would not be able to survive. Despite its weakness, university has to retain its position as the knowledge server which, in turn, can increase people's enthusiasm to seek knowledge. With that enthusiasm, people will do anything to grab knowledge anywhere and anytime. They will employ their resources to obtain knowledge. They will invest their energy to get knowledge.

Prior to building people's enthusiasm, the first thing to do is that university must be able to build its lecturers and student to find knowledge. It has to train lecturers to be resourceful to their student $\mathrm{s}$ with regard to the knowledge bang with occurs in the West lately. University has to motivate the lecturers to use the current trend in their respective discipline in the teaching and learnings activities. University is also responsible to support researches for the sake of the teaching and learning activities, and thus supporting lecturers to write books and publish them through the press. We believe that when the university can anticipate the knowledge bang, the society will see the university as the true knowledge server. This position is hoped to build people's enthusiasm to find knowledge. Then, the society will have greater motivation to find any university's products that can increase their knowledge.

There is no prohibition for university's press to look after profits for their published books. However, the demand for profits must not put aside the sole goal of establishing the university where it located. This is not only related to practical interest but also a matter of policy. The policy has to be made in such a way that the primary concern of the press is establishing the name of the university.

The policy can be succeeded with publishing books that may raise the image of the university. These kinds of books have double functions, that is, (1) raising the universities image with wide target market and (2) raising the university's image but narrow target market. Another categorization of this books is according to wither books (1) are unable to raise the university's image but with wide target market and (2) are unable to raise the university's image and have only narrow target market [15].

What the university's press needs to do is to publish books that belong to the first two group's mentioned above. Therefore, the press must put any efforts for the publication of the books. The efforts are not merely finding good writers and producing perfect books but also looking after support from the university in term of topics worth discussing in books. The last one is hardly to archive. Not many leaders of universities who pay much attention to watch and believe its press. There sold be some attempts that the press needs to do to raise the image of the university. Belonging to thus attempts is to see the press as a cultural and educational institution. With their position, the press's chance to publish qualified books will be greater. In the end, the image of university is raised up.

\section{A. The University's Press Management}

The press across universities has its own organizational structure. Mostly the press named Lembaga Penerbitan Universitas (The University's Press Organization) or technical implementation unit. This is based on observation and survey carried out in the last five years. The role of the press in each university is usually in line with that the leaders of the particular university demand. The vision, mission, goal, and functions of the press are in accordance with those of the university. That is, the organizational structure of the press has to be clear within the broader structure of the university itself. There are some types of organization of Indonesian university's press. Some of them are in the forms of technical implementation unit, $\mathrm{CV}$, foundation, and some others are business organization [16].

Those types of organization have their own strengths and weaknesses. Aside from that, what needs to be taken care of is that the success of the press's management depends on three principals: (1) The location, (2) the university's leader, (3) the managers of the press [17]. Sharing his experiences in managing university's press, suggests that there are four main aspects to be considered, namely the human resources, funding's, equipment, and production and marketing [18].

The management of the press needs to employ the functional approach as stated in the theory of management evolution that is so called as "management by function". This type of management puts emphasis of the operation of each function that is from input to output, with each function works in its own line to archive the best quality. The concept of Total Quality Management (TQM) introduced by Heizer and Render as a Kyzen concept can also be applied in the world of press, such as the university's press [14].

The operational management of university's press consist of, firstly, the editorial Management. In this management, things to do are drafting, creating requirement for manuscript, finding source, reviewing, administering, create copyrights and agreement, and providing ISBN/ISSN. The second operational management is the publishing management. Here, the production of books is carried out, ranging from prepublishing, printing, and post-printing to determining the price 
of the published books. The third is the Marketing and Distribution Management. This management is responsible to market, distribute, store, and widen the line of market and distribution. The last is the Administration and Financial Management which consist of administering, managing the operational costs, counting the profit/loss, publication, and documentation.

Another important role in the press is the existence of the head. Director, or top leader of the management. There are challenges in becoming the head of the university's press. Among the challenge are dealing with the writers, with the rapid development of science and technology, and so on.

The first attitude of the leader of the press needs to have is a great willing to seek manuscripts worth publishing. Despite the low number of book writing by lecturers, the leader has to keep optimistic. One thing to deal with this problem is hunt for manuscript for other places as long as they are worth publishing. However, something's remained missing when the leader him/herself has no experience in writing books. The writing skill of the leader will be an attraction in itself to other writers. When the leader has never experienced him/herself writing books, he/she will have no idea of the long and writing road of publishing books.

A leader of university's press also needs to have big dreams towards the organization he/she is responsible with. The press's works include not only publishing academic books but also achieving its predetermined vision and mission. The leader who think internally will bring no changes to the press; even worst, the press is functioned merely to raise his/her personal image. A good leader is he/she who constantly create innovation with regard to the change of habit from conventional books to e-books and their variation.

The number of Indonesian scientific contribution to the international world of knowledge is low. Therefore, the leader of university's press need to find ways to break that bad record by doing something innovative and revolutionary. While translating foreign book to Indonesia has become the current trend nowadays, translating Indonesian books into foreign languages, particularly English, would be a good idea. Leader of the press should see opportunities for Indonesian academicians to become the sources of knowledge to the international society, not the other way around. However, that goal demand excellent management system, from the planning stage to the distribution.

The innovation created by leader of the press has to give impact to the image of his/her organization. Incapable Press Company is a bad label that every leader of the press needs to avoid. For instance, many university's presses nowadays only publish lecture materials of lecturers into book within limited number. This activity should be cased as it can negatively impact the image of the presses themselves in the eye of internal or external society. The leader should have innovated by, for example, conducting training of writing, editing, and other activities that can add up piles of high quality book manuscript. In term of the material, the leader should seek for local genius who can be promoted to the international society, not merely adoring foreign (Western) academicians.
The leader of university's press also need to implant the spirit of entrepreneurship despite the fact that the press is not an organization meant to gain profit. However, when managed professionally, profit will flow into the cash of the organization if the published books have their own niche and the organization also has numerous qualified writers. Here a leader who can seek opportunities in the market is needed. He/she has to go to bookstores very often to see what topic is trending now. As a result, he/she will have a strong underlying ideas in term of books to be published. In term of writers, it must to be easier to find a writer in universities as there are the place where "intelligent" people gather together. What he/she needs is a creative and innovative management of those people.

University's press is a bridge where universities meet the society. The press as the speaker of scientific society within the campus environment has to be able to give its best shot in terms of the materials, appearance, and language of the books to be published. When the people see that the criteria good, the image of the press will also be good, and vice versa. Books published by the press must have underground along and difficult process. Whenever mistake in grammar or typing are found, the first person to be responsible, according to the people, would be the leader of the press. Therefore, the leader of university's press needs to have a strong sense of editorship. $\mathrm{He} / \mathrm{she}$, of course, was not born with this skill, thus he/she have to learn about it. He/she to have some experience in learning and doing actual editing works during his. /her life. It is from the two experiences that the sense of editorials appears. With this sense, a leader can ensure that the published books have reached the standard of publication and been worth publishing. If a leader does not have this sense of editorship and gets into the top position of the press by chance, he/she needs to attend trainings in editing. He/she should never be hesitating to keep learning. It is through those trainings that he/she could have better skills in editing. When it is not done, he/she is digging his/her own graveyard [19].

\section{B. Lecturer's Quality Improvement: the UNS Potrait}

Sebelas Maret University (UNS), via Academic Books Program conducted by Lembaga Pengembangan Pendidikan (The education Development), has produced many high-quality books. The number of books produced has reached over than 300 books in various disciplines. The books are also highquality and able to compete with profit-oriented publisher. It is proven though constant number of sales in national bookstores such as Gramedia, Karisma, Gunung Agung, and others. This is show that the appearance of books by Sebelas Maret University are able to compete in the national books market. In term of the content, books by UNS contain good materials. This can be shown from of prize (hibah), incentive program, or writing competition. Some of the awards are Hibah Buku Teks Dikti, Insentif Buku Ajar Dikti, Beasiswa Unggulan Bidang Penulis Kemendikbud, Sayembara Buku Pengayaan Pusat Perbukuan, and so on.

These result are not obtained by chance. It is the result of the long and winding publishing road with many internal and external challenges. In the beginning of this programs, many things were skeptical as it was considered as a renaming from its predecessor program called Buku Pegangan Kuliah (BPK). 
The BPK program was useful to support the teaching and learning activities at UNS. Its existence also received a good remark from outside parties since it was able to create good learning atmosphere. Unfortunately, in 2000s this program was stop due to the student's resistance. Their reason was logical: there was not significant improvement in term of the book's quality of materials and appearances. Furthermore, they did not agree with the obligation to pay for thus program which was the university's policy.

With regard to that experience, the university mad an initiative to revitalize the BPK program with the academic books program. However, this is not an easy job as many challenges lied ahead. There was always a problem since the collecting manuscript stage up to the distribution stage. The stage could be divided into preparing to the manuscripts, producing, printing, finishing, and distribution. Within every stage, some supporting program were held. For example, in the preparation stage, discussions on published books were held to inspire the lecturers to write. Moreover, trainings in writing and editing were held to provide the lecturers with skills of writing and editing their own pieces of writing. The importance of those training was that manuscripts was sent down to the press had undergone editing process by their own writers, so the process of the production books went smoother. There were many activities held within the Academic Book Program to increase the lecturer's and the societies, in general interest to read and write.

To the lecturers, writing activity must be no something new as they are engaged with books in their daily routine. Writing is not difficult thing to do with regard to the tri dharma perguruan tinggi. Thus, it seems impossible for the lecturers to not having any pieces of writing in their entire life. It is not to mention that one requirement to be promoted is producing academic books, along with conducting research and doing community services. This fact so that it is impossible for those with high academic position but producing no pieces of writing. The question is how come they get the position with not enough number of writing. Trevitte and Henry suggest that the low productivity of academic writings in higher education is like trees with little or no fruits. Universities are supposed to be like trees that products fruits in every season [20]. In reality, the does not seem right as there are now many universities (as trees) but with low number of publication of scientific works or research report (fruits). This mean that we need to criticize the existence and quality of the trees, why those trees do not produce May fruits. There is something wrong with the mindset of many universities in that they seem to only produce student with bachelor degree. Universities should guide the development of thought and conduct deep study and research on certain disciplines. The result will be scientific works published in the form of books. Therefore, universities which have not been produced the works of their lecturers can be considered as failing to do their sole function strategically, making the analogy of trees with less fruits appropriate [21].

Steps in writing books that are developed by UNS is the ones which are inspiring. The first step is to find books which later will be considered as "references". The term "references" here refers to book which serve as ideal models. With this kind of books in mind, the academicians will get inspiration to write, be it in terms of materials or else. Many things can be learned from the references books, from their content, looks, and their language. The second step is to use attractive and communicative style of language. Language as a media of communication plays an important role in determining quality of the book. It has to be easily understood and smooth. To produce such language, much reading is required. Furthermore, a writer needs to be focused and have a great willing to share the knowledge to others. Another important key is to master the materials of books itself so that a deep and sharp analysis can be served. A writer can also add the materials with some "seasoning" in the form of illustrations or inspiring stories. This will activate the work of the left and right brain hemispheres of the readers so that they can graphs the materials well. In summary, write book that can activate both hemispheres of the brain, and you will find that your books can not only entertain but also make you readers smart.

\section{Conclusion}

University's press is the most important pillar in the implementation of tri dharma perguruan tinggi and has vital role in publishing and distributing the university's intellectual assets to the society. Good management of the press will lead to a more professional works. Several aspects need to be taken into account: (1) editorial management, which includes preparing manuscript, requirement of manuscript, their sources, reviewing the manuscripts, the administrative work, copy right, and ISBN/ISSN. (2) Production management, which includes all step in producing books (pre-printing, printing, and after printing) and book pricing; (3) marketing and distribution management, which includes the markets, storing, networking, and distributing; and (4) administration and financial management. The experience of Sebelas Maret University proves that whenever the press is well-managed, the university can obtain positive impacts. The academic atmosphere will always be there within every activity that deals with publication. The Textbook Program at UNS is a good sign. However, in every policy lies positive and negative side, thus requiring continuous evaluation for better implementation in the future.

\section{ACKNOWLEDGMENT}

Ministry of Research, Technology and Higher Education of the Republic of Indonesia that have provided funding for this research

\section{REFERENCES}

[1] Core, A., Publisher as Gatekeepers of Idea, Philip G. Altbach (Ed.). Perspective of Publishing, Lexington: Lexington Books, 1976

[2] Ishak, Mohamed Mustafa, Universiti dan Penerbitan Ilmiah di Malaysia, Hamedi Mohd Adnan (Ed.) Penerbitan Malaysia-Indonesia: Mengukuhkan Jaringan Penerbitan Serantau. Kuala Lumpur: Publisher Universiti Malaya. 2006,p52

[3] Potts, Anthony, Selling University Reform: The University of Melbourne and the Press, Studies in Higher Education, 2012, 37(2), p157-169

[4] Dougherty, Peter J., Publishing: Academic and University Presses, International Encyclopedia of the Social \& Behavioral Sciences (Second Edition), 2015, p624-630

[5] Law No 14 of 2005 on Teachers and Lecturers 
[6] Saddhono, Kundharu, Manajemen University Press; Kajian di Jawa Tengah dan DIY, Surakarta: CakraBooks, 2016, p5

[7] Djamara, R. Tabrani, Direktori Grafika dan Media 2007-2008. Jakarta: Pusat Grafika Indonesia Departemen Pendidikan Nasional, 2007

[8] Riyadhi, et al.. Pedoman dan Pengelolaan University Press. Jakarta: Pusat Grafika Indonesia Departemen Pendidikan Nasional. 2006,p11

[9] Howard, Jennifer, Textbook Sales Drop, and University Presses Search for Reasons, Chronicle of Higher Education, 2008, 55(4), p10

[10] Trevitte, Chad; Henry, Charles, The Rice University Press Initiative: An Interview with Charles Henry, Innovate: Journal of Online Education, 2007, 4(1)

[11] Howard, Jennifer, University Press Meeting Dominated by Donor Proposal and Digital Publishing, Chronicle of Higher Education, 53(43), p12

[12] Abrar, Ana Nadhya. Gaya Penerbitan Buku University Press. Seminar and Workshop University Press Jakarta: Pusat Grafika Indonesia Departemen Pendidikan Nasional, 2006a.

[13] Abrar, Ana Nadhya. 2006b. Siapa Sebenarnya Direktur University Press. Hamedi Mohd Adnan (Ed.). Penerbitan Malaysia-Indonesia:
Mengukuhkan Jaringan Penerbitan Serantau. Kuala Lumpur: Penerbit Universiti Malaya, 2006b.

[14] Riyadhi, et al.. Pedoman dan Pengelolaan University Press. Jakarta: Pusat Grafika Indonesia Departemen Pendidikan Nasional. 2006,p11

[15] Riyadhi, et al.. Pedoman dan Pengelolaan University Press. Jakarta: Pusat Grafika Indonesia Departemen Pendidikan Nasional. 2006,p15

[16] Djamara, R. Tabrani, Direktori Grafika dan Media 2007-2008. Jakarta: Pusat Grafika Indonesia Departemen Pendidikan Nasional, 2007

[17] Riyadhi, et al.. Pedoman dan Pengelolaan University Press. Jakarta: Pusat Grafika Indonesia Departemen Pendidikan Nasional. 2006,p28

[18] Razak, Arifzan, Struktur Organisasi dan Rincian Tugas University Press, Seminar and Workshop University Press, Jakarta: Pusat Grafika Indonesia Departemen Pendidikan Nasional. 2006

[19] Trevitte, Chad and Henry, Charles. 2007. "The Rice University Press Initiative: An Interview with Charles Henry. Innovate: Journal of Online Education, 4(1)

[20] Parrott, John B. 2010. "Yale University Press: Disseminating 'Lux et Veritas"'. Academic Questions 23(3) 327-338

[21] Potts, Anthony. 2012. "Selling University Reform: The University of Melbourne and the Press". Studies in Higher Education.37(2) 157-169 